Check for updates

Cite this: RSC Chem. Biol., 2022, 3,220

Received 5th December 2021,

Accepted 21st December 2021

DOI: 10.1039/d1cb00235j

rsc.li/rsc-chembio

\section{Combating amyloid-induced cellular toxicity and stiffness by designer peptidomimetics $\dagger$}

\author{
Mouli Konar, \$ Debasis Ghosh, $\$$ Sourav Samanta and Thimmaiah Govindaraju (D) *
}

\begin{abstract}
Amyloid beta (A $\beta$ ) aggregation species-associated cellular stress instigates cytotoxicity and adverse cellular stiffness in neuronal cells. The study and modulation of these adverse effects demand immediate attention to tackle Alzheimer's disease (AD). We present a de novo design, synthesis and evaluation of Aß14-23 peptidomimetics with cyclic dipeptide (CDP) units at defined positions. Our study identified Akd $^{\text {NMC }}$ with CDP units at the middle, $\mathrm{N}$ - and $\mathrm{C}$-termini as a potent candidate to understand and ameliorate $A \beta$ aggregation-induced cellular toxicity and adverse stiffness.
\end{abstract}

\section{Introduction}

Aberrant aggregation of $\mathrm{A} \beta$ peptides and their extracellular deposition in the human brain are the major hallmarks of AD. ${ }^{1-3}$ Compelling evidence suggests that the accumulation of amyloid aggregation species in brain tissue induces significant stress on neurons through cell membrane interactions. ${ }^{4-7}$ This causes redox imbalance and reorganization of the cytoskeletal system of neuronal cells. ${ }^{4} \mathrm{~A} \beta$ aggregation species elicit endoplasmic reticulum (ER) stress and oxidative stress through the production of excessive reactive oxygen species (ROS)., ${ }^{6,7}$ Although there are cellular pathways to reverse the stress, the adverse outcome of this pathogenic situation is cell apoptosis. Under the amyloid-induced stress conditions, the cells become rough and rigid due to the polymerization and stiffening of cytosolic actin filaments leading to the formation of stress fibres. ${ }^{8-11}$ Atomic force microscopy (AFM)-based advanced imaging techniques are some of the best methods to assess such amyloidinduced physio-mechanical changes in the cells. ${ }^{12-15}$ PeakForce Quantitative NanoMechanics-AFM (PF QNM-AFM) offers high

Bioorganic Chemistry Laboratory, New Chemistry Unit and School of Advanced Materials (SAMat), Jawaharlal Nehru Centre for Advanced Scientific Research, Jakkur P.O., Bengaluru 560064, Karnataka, India. E-mail: tgraju@jncasr.ac.in $\dagger$ Electronic supplementary information (ESI) available. See DOI: 10.1039/ d1cb00235j

\$ These authors contributed equally to this work. resolution imaging of cells with real-time spatial resolution mapping of the nanoindentation parameter Derjaguin-Muller-Toporov (DMT) modulus (measure of stiffness). ${ }^{16,17}$ In this study, special emphasis is given to understanding the neuronal cells under amyloid-induced cellular stress conditions and their rescue by de novo designed peptidomimetics inhibitors employing confocal and PF QNM-AFM techniques.

Natural peptide-based amyloid inhibitors offer numerous advantages over small molecule inhibitors ${ }^{18-21}$ owing to their biological origin, biocompatibility, target-specific binding, sequence variability and ease of synthesis. ${ }^{22-29}$ Short peptides with ${ }^{16} \mathrm{KLVFF}^{20}$ derived from $\mathrm{A} \beta 42$ have been shown to inhibit $\mathrm{A} \beta$ aggregation. ${ }^{30-33}$ The propensity of natural peptides for proteolytic cleavage and self-aggregation has led to the development of peptidomimetics-based inhibitors such as peptoids and cyclic peptides. ${ }^{34-37}$

We hypothesized that the incorporation of rigid, proteolytically stable CDP units into A $\beta 14-23$ at defined positions would overcome the limitations of linear peptides and the cytotoxicity and flexibility issues often associated with large cyclic peptide-based amyloid modulators. The exceptional intermolecular hydrogen bonding ability and biological activities of CDPs are anticipated to control $A \beta$ aggregation and associated stress-induced cellular mechanical changes through interactions with $A \beta$ monomers or aggregation species. ${ }^{38-40}$

We designed and synthesized a set of A $\beta 14-23$ (I) peptidomimetics by incorporating cyclo(Lys-Asp)-based CDP-unnatural amino acid $(\mathrm{kd})$ at the middle $\left(\mathrm{Akd}^{\mathrm{M}}, \mathrm{II}\right), \mathrm{C}$-terminal $\left(\mathrm{Akd}^{\mathrm{C}}, \mathrm{III}\right), \mathrm{N}$-terminal $\left(\mathrm{Akd}^{\mathrm{N}}, \mathrm{IV}\right)$, and at all three positions $\left(\right.$ Akd $\left.^{\mathrm{NMC}}, \mathrm{V}\right)$ (Fig. 1, detailed characterizations in ESI, $\dagger$ Tables S1 and S2). The resemblance between $A \beta 14-23$ (I) and $A \beta 42$ (the most toxic form of $\mathrm{A} \beta$ ) in their $\mathrm{pH}$-dependent aggregation, metal binding and cytotoxic properties ${ }^{32,41-43}$ prompted us to investigate the aggregation behaviour of $\mathrm{I}$ in the presence of II-V in pH 2.0 (glycine-HCl buffer, $10 \mathrm{mM}$ ) and pH 7.4 (PBS: phosphate buffer saline, $10 \mathrm{mM}$ ) conditions. First, we sought to identify a competitive in vitro inhibitor of $\mathrm{A} \beta 14-23$ aggregation from II-V. Thereafter, we aimed to evaluate the efficiency of the 


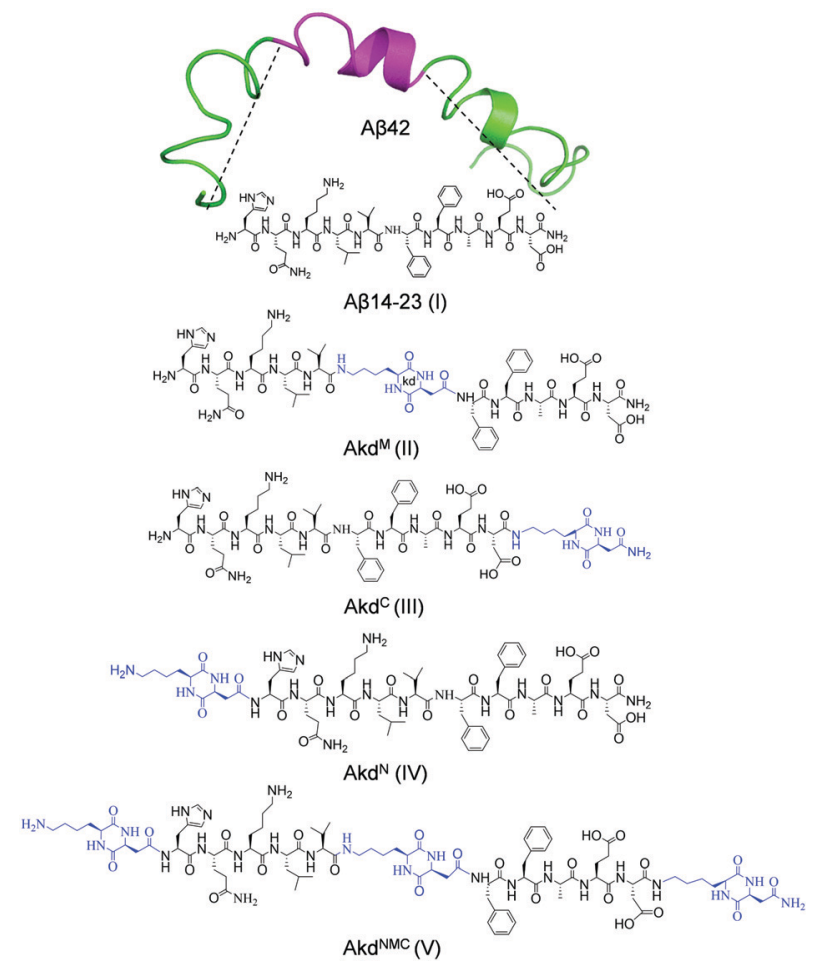

Fig. 1 Structures of A $\beta 14-23$ (I) derived from A $\beta 42$ (PDB: 1Z0Q) and CDP $(\mathrm{kd})$ inserted peptidomimetics $(\mathrm{II}-\mathrm{V})$.

lead inhibitor to ameliorate cellular toxicity and adverse cell mechanics caused by A $\beta 42$ amyloid-induced cellular stress.

\section{Results and discussion}

A time-dependent thioflavin $\mathrm{T}$ (ThT) fluorescence assay was performed to assess the aggregation kinetics of AB14-23 and determine the aggregation rate constant $(\kappa)$ and lag time $\left(T_{\text {Lag }}\right)$ upon treatment with $\mathrm{II}-\mathrm{V}$ for 20 days at two $\mathrm{pH}$ conditions (Fig. 2a-c). The aggregation of A $\beta 14-23$ plateaued after 6 and 15 days under the $\mathrm{pH} 2.0$ and 7.4 conditions, respectively. $\mathrm{A} \beta 14-23$ showed a faster aggregation of $\kappa=1.1 \mathrm{day}^{-1}$ at $\mathrm{pH} 2.0$ as compared to that at pH $7.4\left(\kappa=0.5 \mathrm{day}^{-1}\right)$. The co-incubation of $\mathrm{A} \beta 14-23$ with II-V distinctly influenced its aggregation propensity. A $\beta 14-23$ treatment with $\mathrm{V}$ resulted in the longest $T_{\text {Lag }}(199.2$ and $316.8 \mathrm{~h}$ for $\mathrm{pH} 2.0$ and 7.4, respectively) with low $\kappa$ values $\left(\sim 0.4\right.$ day $\left.^{-1}\right)$. This data suggests the effective interaction of $V$ with $\mathrm{A} \beta 14-23$ at the lag phase and stabilization of the monomeric state. The $T_{\mathrm{Lag}}$ values for the II $(100.8$ and $216.0 \mathrm{~h}$ in $\mathrm{pH} 2.0$ and 7.4, respectively) and III (120.0 and $124.8 \mathrm{~h}$ in $\mathrm{pH} 2.0$ and 7.4, respectively) treated $\mathrm{A} \beta 14-23$ samples suggest monomer stabilization albeit to a lesser extent as compared to V. Relatively better inhibitory efficiency was observed for II compared to III. Meanwhile, IV was found to enhance the aggregation rate of A 314 23 by shortening $T_{\text {Lag }}(60.1$ and $54.2 \mathrm{~h}$ in $\mathrm{pH} 2.0$ and 7.4, respectively). The higher $\kappa$ for IV-treated A $\beta 14-23$ is attributed to the rapid aggregation of monomers into growth-directing critical nuclei at the lag phase. The kinetic analysis thus inferred that II, III, and V inhibited Aß14-23 aggregation under both acidic and (a)
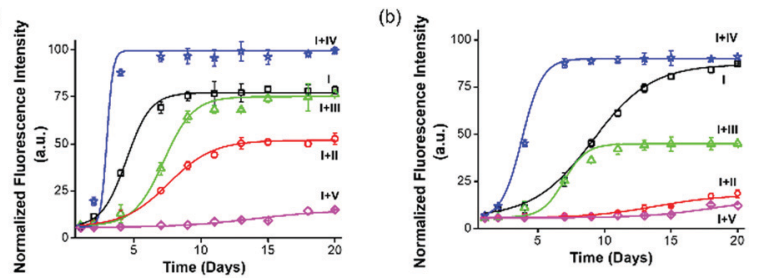

\begin{tabular}{|c|c|c|c|c|}
\hline Sample & \multicolumn{2}{|c|}{$\begin{array}{c}\text { Aggregation rate constant } \kappa(\text { day } \\
\mathrm{pH}) \text { at } \\
\mathrm{pH} 7.4\end{array}$} & \multicolumn{2}{|c|}{$\begin{array}{c}\text { Lag Time } T_{\text {Lag }}(\mathrm{h}) \text { at } \\
\mathrm{pH} 2.0\end{array}$} \\
\hline $\mathrm{I}$ & 1.1 & 0.5 & 62.4 & 110.4 \\
\hline $\mathrm{I}+\mathrm{II}$ & 0.6 & 0.4 & 100.8 & 216.0 \\
\hline $\mathrm{I}+\mathrm{II}$ & 0.9 & 1.1 & 120.0 & 124.8 \\
\hline $\mathrm{I}+\mathrm{IV}$ & 4.4 & 1.3 & 60.1 & 54.2 \\
\hline $\mathrm{I}+\mathrm{V}$ & 0.4 & 0.4 & 199.2 & 316.8 \\
\hline
\end{tabular}
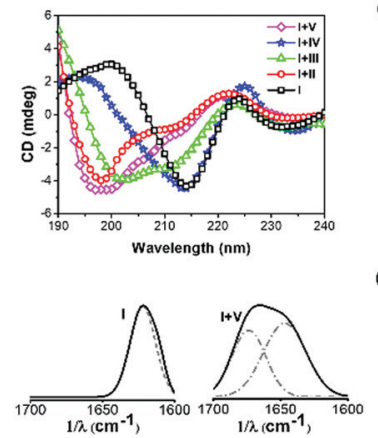
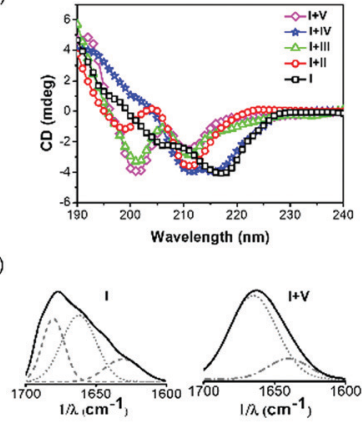

Fig. 2 A $1414-23$ (I) aggregation in the absence and presence of II, III, IV and $\mathrm{V}$ at $\mathrm{pH} 2.0$ (left panel) and 7.4 (right panel) for 20 days. ( $\mathrm{a}$ and $b$ ) Timedependent ThT fluorescence $\left(\lambda_{\mathrm{em}}=482 \mathrm{~nm}\right)$ assay data, (c) I aggregation parameters, $\kappa$ and $T_{\text {Lag, }}(\mathrm{d}$ and e) CD spectra, and (f and g) deconvoluted FTIR spectra (amide I region: $1600-1700 \mathrm{~cm}^{-1}$, solid line) at $\mathrm{pH} 2.0$ and 7.4, respectively. Dotted-line: $\alpha$-helix, dotted-dashed line: random coil and dashed-line: $\beta$-sheet.

physiological conditions. The position of kd in peptidomimetics plays a crucial role in the modulation of A $144-23$ aggregation. Peptidomimetics with single kd at the middle (II) or C-terminal (III) and three kd units at the middle, $\mathrm{N}$ - and $\mathrm{C}$-termini (V) are effective modulators of A $\beta 14-23$ aggregation with overall inhibitory efficiency in the order of V > II > III. In contrast, IV with kd at the N-terminal exhibited propensity for enhancing amyloid aggregation.

$A \beta$ undergoes aggregation through conformational changes from random coil to $\alpha$-helix to $\beta$-sheet. ${ }^{41}$ We performed circular dichroism (CD) and Fourier transform infrared (FTIR) studies to understand the effect of $\mathrm{II}-\mathrm{V}$ on A $\mathrm{A} 14-23$ aggregationinduced secondary conformations. The negative ellipticity around $218-220 \mathrm{~nm}(\sim-4-4.2 \mathrm{mdeg})$ in the CD spectra of $\mathrm{A} \beta 14-23$ at both $\mathrm{pH}$ conditions confirmed its aggregation through the $\beta$-sheet structure (Fig. $2 \mathrm{~d}$ and e). Upon incubation with II, III and V at pH 2.0, the CD band at $218 \mathrm{~nm}(-4.2 \mathrm{mdeg})$ was shifted to $200 \mathrm{~nm}(-3.4,-3.6$, and $-4.5 \mathrm{mdeg})$ suggesting the stabilization of $A \beta 14-23$ monomers with the random coil conformation (Fig. 2d). The random coil and $\beta$-sheet features observed upon treatment with III indicated its moderate effect in stabilizing A 1 14-23 monomers. Further, the negative bands around 200 and $210 \mathrm{~nm}$ (around -4 and $-3 \mathrm{mdeg}$, respectively) at $\mathrm{pH} 7.4$ suggested the monomer stabilization of $\mathrm{A} \beta 14-23$ through random coil and $\alpha$-helix conformations, respectively, 
in the presence of II, III and V (Fig. 2e). Meanwhile, the CD spectra of IV-treated $A \beta 14-23$ showed broad negative bands around 216-218 nm (-3.9 mdeg), which confirmed the $\beta$-sheet-driven aggregation at both $\mathrm{pH}$ conditions. The weak positive CD signal ( $\sim 0.8 \mathrm{mdeg}$ ) observed for $\mathrm{I}$ at $\mathrm{pH} 2.0$ is possibly attributed to the twisted nature of the aggregates as revealed by the transmission electron microscopy (TEM) study (Fig. S1, ESI $\dagger$ ). ${ }^{44}$ The amide I region $\left(1600-1700 \mathrm{~cm}^{-1}\right)$ of the FTIR spectra confirmed the aggregation propensity of A $\beta 14-23$ with characteristic features of parallel $\left(1620 \mathrm{~cm}^{-1}\right)$ and antiparallel (1620 and $1680 \mathrm{~cm}^{-1}$ ) $\beta$-sheet conformations at $\mathrm{pH} 2.0$ and 7.4, respectively (Fig. $2 \mathrm{f}$ and $\mathrm{g}$ ). ${ }^{45}$

Aß14-23 samples incubated with II-IV showed significant $\beta$-sheet characteristics at both $\mathrm{pH}$ conditions (Fig. S2, ESI $\dagger$ ). Under similar conditions, treatment with $\mathrm{V}$ induced either random coil (1640 and $\left.1670 \mathrm{~cm}^{-1}\right)$ or $\alpha$-helix $\left(1660 \mathrm{~cm}^{-1}\right)$ features, confirming its potential to stabilize A $\beta 14-23$ monomers. The ${ }^{1} \mathrm{H}$ NMR study validated the stabilization of the monomeric state of I by V (Fig. S3, ESI $\dagger$ ).

AFM data showed the formation of topographically and morphologically distinct aggregates by $\mathrm{A} \beta 14-23$ at two $\mathrm{pH}$ (2.0 and 7.4) conditions (Fig. 3). The short fibril-like compact aggregates (average height $\sim 3-5 \mathrm{~nm}$ ) and typical oligomerassociated elongated fibrils (average height $\sim 1-2 \mathrm{~nm}$ ) were observed at pH 2.0 and 7.4, respectively. TEM revealed that $\mathrm{A} \beta 14-23$ formed short twisted fibrils at $\mathrm{pH} 2.0$ and elongated fibrils with oligomers at $\mathrm{pH} 7.4$ (Fig. S1, ESI $\dagger$ ). The formation of short fibril-like aggregates at lower $\mathrm{pH}$ is anticipated to follow the non-cooperative elongation mechanism. ${ }^{46}$ Inhibition of A $\beta 14-23$ aggregation by II, III and V was confirmed by both AFM and TEM studies with inhibition efficacy in the order of V > II > III (Fig. 3 and Fig. S1, ESI $\dagger$ ). The abundant fibrillar aggregates of the IV-treated $A \beta 14-23$ sample $(\mathrm{I}+\mathrm{IV})$ reiterated the fibrillation promoting nature of IV.

Next, we assessed the cytotoxicity of II-V in cultured neuronal cells $(S H-S Y 5 Y)$. The treatment of cells with II-V $(10 \mu \mathrm{M})$ for $24 \mathrm{~h}$ showed cell viabilities of $\sim 93 \%$, 99\%, 99\%, and 99\%, respectively, compared to the PBS-treated (10 mM, pH 7.4) control (100\%) (Fig. S4a and b, ESI $\dagger$ ). This result suggests the excellent viability and biocompatibility of II-V to neuronal cells. To evaluate the efficacy of the peptidomimetics to rescue the cells from Aß14-23-aggregation-induced cytotoxicity, the cells were treated with $\mathrm{A} \beta 14-23(10 \mu \mathrm{M})$ in the absence and presence

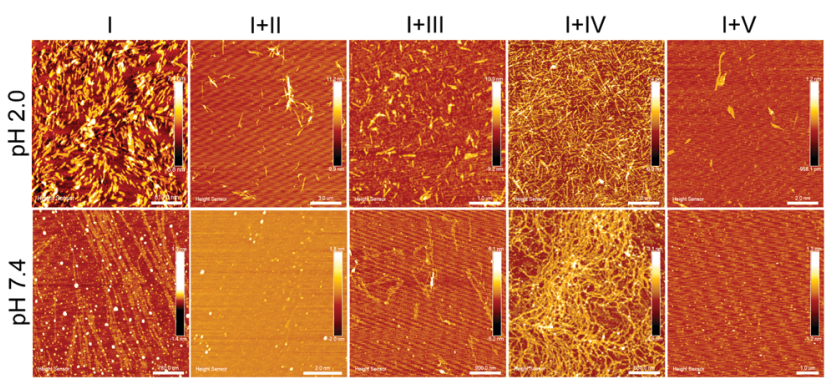

Fig. 3 AFM images of pre-incubated A $\beta 14-23$ (I) in the absence and presence of $\mathrm{II}-\mathrm{V}$. of II-V at 1:1 stoichiometric ratios. As expected, A $\beta 14-23$ treatment showed reduced cell viability of $\sim 66 \%$, which confirmed its neurotoxic nature. The cells treated with $A \beta 14-23$ in the presence of II-V showed $\sim 90 \%, 83 \%, 69 \%$ and $97 \%$ cell viability, respectively, which corresponds to $\sim 24 \%, 17 \%, 3 \%$, and $31 \%$ improved viability over the A $\beta 14-23$-treated cells (Fig. S4c, ESI $\dagger$ ). From these results, we identified II and V as potential inhibitors of A $\beta 14-23$-induced in cellulo toxicity. The effects of I-V on A $\beta 42$-induced toxicity were further assessed by treating the cells with $\mathrm{A} \beta 42(10 \mu \mathrm{M})$ with $\mathrm{I}-\mathrm{V}$ at $1: 1$ ratios for 24 h (Fig. S4d, ESI $\dagger$ ). A $\beta 42$ alone showed cell viability of $\sim 64 \%$, indicating its highly toxic nature towards $S H-S Y 5 Y$ cells. The cells incubated with $\mathrm{A} \beta 42$ in the presence of $\mathrm{I}-\mathrm{V}$ showed viabilities of $\sim 47 \%, 72 \%, 68 \%, 67 \%$, and $97 \%$, respectively. Notably, A $\beta 42+$ I showed severe cytotoxicity to the cells due to the high aggregation propensity of both I and A $\beta 42$. Remarkably, V showed a strong neuronal rescue with $\sim 33 \%$ improved viability compared to the A 342 -treated cells. These results motivated us to perform a detailed evaluation of the inhibitory potential of $\mathrm{V}$ against amyloid-induced alterations at cellular levels using confocal imaging-based immunocytochemistry, fluorescence imagingbased live/dead assay and modulation of ROS generation. The ThT, CD, AFM and TEM-based biophysical data of A $\beta 42$ and $\mathrm{A} \beta 42+\mathrm{V}$ are in good agreement with in cellulo studies and support $\mathrm{V}$ as a potential inhibitor of $\mathrm{A} \beta$ aggregation at $\mathrm{pH} 7.4$ (Fig. S5, ESI $\dagger$ ).

Immunocytochemistry assays unambiguously evaluate the efficiency of an inhibitor to prevent the membrane-localization of $\mathrm{A} \beta 42$ aggregates by stabilizing the nontoxic monomers. ${ }^{47}$ For this study, the $S H$-SY5Y cells were incubated independently with $\mathrm{A} \beta 42, \mathrm{~A} \beta 42+\mathrm{I}$, and $\mathrm{A} \beta 42+\mathrm{V}$ at $\mathrm{pH} 7.4$ for $3 \mathrm{~h}$ followed by successive staining with fibril-specific primary antibody (OC), fluorescent-labelled secondary antibody $\left(\lambda_{\mathrm{ex}}=633 \mathrm{~nm}\right.$ and $\lambda_{\mathrm{em}}=$ $650 \mathrm{~nm}$ ) and DAPI (nuclear staining dye). The confocal microscopy images showed the localization of $A \beta$ aggregates in abundance on the cell membrane both in A $\beta 42$ (12.3\%, total area covered by red fluorescence-labelled $A \beta$ aggregates) and $A \beta 42+I$ (13.3\%) treated cells, while $\mathrm{A} \beta 42+\mathrm{V}$ displayed significant reduction of membranelocalized aggregates (1.5\%) indicating the amyloid inhibitory potential of $\mathrm{V}$ under cellular conditions (Fig. 4a, Fig. S4e and f, $\mathrm{ESI} \dagger$ ). We also performed a live/dead assay to confirm the cytotoxicity of $\mathrm{A} \beta 42$ and neuronal rescue from amyloid-induced stress upon treatment with V. The $S H-S Y 5 Y$ cells were cultured in a $35 \mathrm{~mm}$ confocal dish and treated with calcein-AM $(2 \mu \mathrm{M})$ and propidium iodide $(4.5 \mu \mathrm{M})$ to stain the live (green) and dead (red) cells, respectively. The fluorescence images displayed a significant extent of dead cells present in the A $\beta 42(10 \mu \mathrm{M})$ treated samples (Fig. $4 \mathrm{~b}$ and Fig. S6, ESI $\dagger$ ). Meanwhile, the samples treated with $A \beta 42+\mathrm{V}$ $(10 \mu \mathrm{M}, 1: 1)$ showed an appreciable reduction in the number of dead cells. Quantitatively, the Image J analysis revealed that the A $\beta 42$ treated samples contained $\sim 36 \%$ dead cells, which reduced to $\sim 4 \%$ in the presence of $\mathrm{V}$ compared to the PBS-treated controls. These findings have proved that $\mathrm{V}$ successfully attenuates $\mathrm{A} \beta 42$ aggregation-induced toxicity under in cellulo conditions.

We have demonstrated the role of A 342 in excessive ROS production and oxidative stress in previous studies. ${ }^{18,24}$ Here, 
(a) DAPI

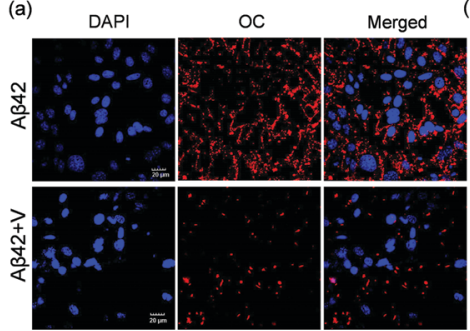

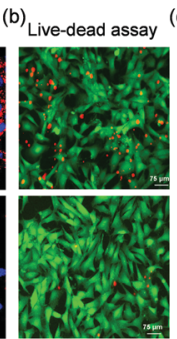

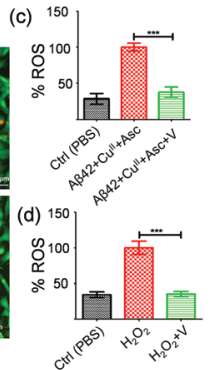

Fig. 4 (a) Confocal images of $A \beta 42(10 \mu M)$ and $A \beta 42+V(10 \mu M, 1: 1)$ treated SH-SY5Y cells in PBS $(\mathrm{pH}$ 7.4) immunostained with $\mathrm{OC}$ and secondary antibody (red). Blue: nuclear staining with DAPI. Scale bar: $20 \mu \mathrm{m}$. (b) Fluorescence microscopy images of SH-SY5Y cells upon treatment with $A \beta 42(10 \mu M)$ and $A \beta 42+V(1: 1)$ for $24 \mathrm{~h}$. Green: staining with calcein AM, red: staining with propidium iodide. (c) Intracellular ROS generation in SH-SY5Y cells incubated with Aß42 $(10 \mu \mathrm{M}), \mathrm{Cu}^{\prime \prime}(10 \mu \mathrm{M})$, ascorbate $(300 \mu \mathrm{m})$, in the absence and presence of $\mathrm{V}(10 \mu \mathrm{M})$. (d) ROS levels measured in $\mathrm{SH}$-SY5Y cells upon incubating (4 h) with $\mathrm{H}_{2} \mathrm{O}_{2}$ in the absence and presence of $\mathrm{V}$. ROS produced is quantified by measuring DCF fluorescence emission at $529 \mathrm{~nm}$ for a given time point. Each experiment was repeated three times $(n=3)$, and the error bars represent the standard deviation (SD) (* $p<0.0001)$

we attempted to evaluate the role of $\mathrm{V}$ in reducing ROS levels in A $\beta 42$-induced amyloidogenic conditions. Intracellular ROS levels in $S H$-SY5Y cells (in the form of hydroxyl and peroxyl radicals) were investigated using DCFDA (2,7-dichlorofluorescein diacetate) fluorescence dye. In this study, $\mathrm{A} \beta 42-\mathrm{Cu}^{\mathrm{II}}(10 \mu \mathrm{M})$, ascorbate $(300 \mu \mathrm{M})$, and $\mathrm{A} \beta 42-\mathrm{Cu}^{\mathrm{II}}+\mathrm{V}(10 \mu \mathrm{M})$ were added to DCFDA-treated $S H-S Y 5 Y$ cells and the DCF fluorescence was monitored at $529 \mathrm{~nm}$. Our data revealed that V significantly reduced the ROS level produced by the A $\beta 42-\mathrm{Cu}^{\mathrm{II}}+$ Asc system in cells to $\sim 38 \%$ (Fig. $4 \mathrm{c}$ ). The cellular study also demonstrated that $\mathrm{V}$ effectively reduces the exogenously added $\mathrm{H}_{2} \mathrm{O}_{2}$ to $\sim 35 \%$ (Fig. 4d). Overall, $\mathrm{V}$ acts as an effective amyloid inhibitor and modulator of amyloid-induced excessive ROS generation and related cellular stress.

PF QNM-AFM was employed to gain insights into the changes in the physio-mechanical properties of the cell membrane due to A $\beta 42$-induced cellular stress and the rescuing effect of V. From the PF QNM-AFM data, we evaluated parameters such as the height, peak force error (a measure of exact tip-surface interactions) and cell stiffness (DMT modulus) with spatial resolution for both single (Fig. 5a-c) and a colony of $S H-S Y 5 Y$ cells (Fig. S7, ESI $\dagger$ ) treated with $A \beta 42$ and $A \beta 42+V$ for 24 h. Fig. $5 \mathrm{a}$ shows smooth topography (height $5.4 \pm 0.6 \mu \mathrm{m}$ ) with low mechanical stiffness $(30 \pm 5 \mathrm{kPa})$ for the control cells, where no sign of stress fiber formation was observed. The smooth topography and mechanical stiffness of $30 \pm 5 \mathrm{kPa}$ indicate healthy cellular characteristics of the control cells. ${ }^{11}$ Upon $\mathrm{A} \beta 42$ treatment, the cells were deformed (height $1.6 \pm 0.2 \mu \mathrm{m}$ ) with increased cell stiffness $(417 \pm 39 \mathrm{kPa})$ and the formation of networks of stress-fibers was observed (indicated by the arrows). The stress-fiber-containing deformed cellular features with rigid mechanics (high stiffness) indicate the emergence of stress due to $\mathrm{A} \beta$-membrane interactions. ${ }^{9-11}$ Remarkably, $\mathrm{A} \beta 42+\mathrm{V}$ treated cells showed cell morphology (height $6.4 \pm 0.4 \mu \mathrm{m}$ ), stiffness
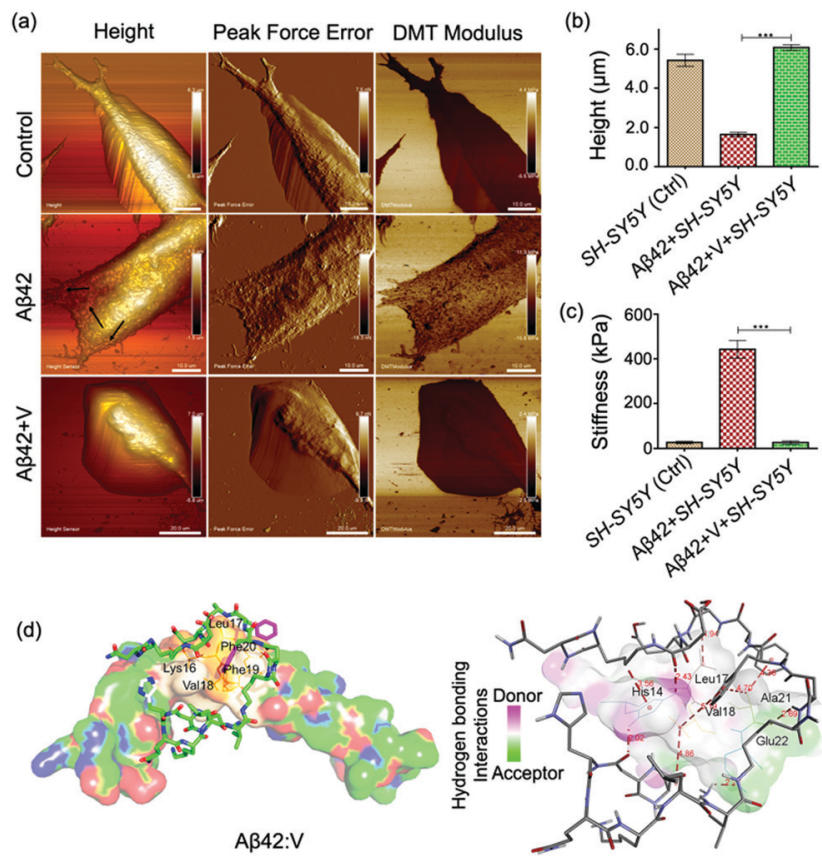

Fig. 5 PF QNM-AFM images of SH-SY5Y cells under healthy and amyloidinduced stress conditions in height, peak force error and DMT modulus modes. The cells treated with (a) PBS, pH 7.4 (control), A $\beta 42$ and A $\beta 42+\mathrm{V}$. Arrows in the A $\beta 42$-treated cells indicate stress fibers. ( $b$ and $c$ ) Height and mechanical stiffness calculated from the PF QNM-AFM data. Number of experiments $=3$, mean $\pm \mathrm{SD},{ }^{*} p<0.001$. (d) Representative docked conformation between $A \beta 42$ (surface representation) and $V$ (stick representation) (Left) and their possible interactions based on the hydrogen bonding donor-acceptor sites in the 14-23 region of $A \beta 42$ (surface, Right).

$(21 \pm 9 \mathrm{kPa})$ and cytoskeletal organization comparable to the control cells. This affirmatively validated $\mathrm{V}$ as a potential candidate to combat amyloid-induced cellular stress and to maintain healthy cellular mechanics.

We performed molecular docking to investigate the binding interactions between $A \beta 42$ and V. The docking results showed that $\mathrm{V}$ binds to $\mathrm{A} \beta 42$ with a binding energy of $-5.2 \mathrm{kcal} \mathrm{mole} \mathrm{k}^{-1}$ (Table S3, ESI $\dagger$ ). The data in Table S3 (ESI $\dagger$ ) also indicate that KLVFF recognition plays an important role in the binding of $\mathrm{V}$ around the 14-23 region of $A \beta 42$. Multiple hydrogen bonding and hydrophobic interactions via the His14, Leu17, Val18, Ala21 and Glu22 residues of $\mathrm{A} \beta 42$ and the $\mathrm{kd}$ residues of $\mathrm{V}$ are found to stabilize the hydrophobic 14-23 region (Fig. 5d). V-mediated spatial interactions with $\mathrm{A} \beta 42$ can segregate the $\mathrm{A} \beta 42$ monomers and thus inhibit amyloid aggregation inhibition, as revealed by the spectroscopy data. Further, the docking analyses revealed $\mathrm{V}$ as the most effective amyloid inhibitor, which stabilized A $\beta 14-23$ monomers through KLVFF recognition (Fig. S8 and Table S4, ESI $\dagger$ ). The innocuous inhibitor V was found to exhibit significant stability against the enzymatic (trypsin) degradation and non-self-aggregation property as confirmed by timedependent AFM studies (Fig. S9 and S10, ESI $\dagger$ ). It should be noted that IV exhibited self-aggregation (ThT fluorescence studies, Fig. S11, ESI $\dagger$ ), which explains its aggregationenhancing behaviour towards I. 
Analyses of the experimental and theoretical results reveal that a single kd unit at the N-terminal (IV) is far away from the aggregation inducer region with $\mathrm{FF}$, which explains the inability of IV to stop the self-aggregation of I; instead, it serves as an $\mathrm{A} \beta$ aggregation enhancer through the $\beta$-sheet structure (Fig. S8, ESI $\dagger$ ). Interestingly, the incorporation of kd units close to FF (II, III and V) of I was found to effectively stabilize the $A \beta$ monomers through multiple hydrogen bonding and other noncovalent interactions (Fig. 5d). The highest $A \beta$ aggregationinhibition of $\mathrm{V}$ is not only attributed to the presence of multiple kd units but also to their positions, especially at the middle and C-terminus (Tables S3 and S4, ESI + ). The docked structures of $\mathrm{A} \beta 42: \mathrm{V}$ and I:V suggest that the binding sites of the middle and C-terminal kd units are suitably positioned to provide maximum interaction around KLVFF to stabilize the $\mathrm{A} \beta$ monomer, while the kd unit at the $\mathrm{N}$-terminal offers supporting interactions.

In summary, $A \beta 14-23$ peptidomimetics incorporated with CDP units (kd) effectively combat amyloid-induced membrane toxicity, excessive ROS production and adverse cellular mechanics under stress conditions. Our study demonstrated that AB14-23 peptidomimetics with three kd units at the $\mathrm{N}$ - and C-termini and middle $(\mathrm{V})$ is a potent inhibitor of amyloid aggregation of both $A \beta 14-23$ and $A \beta 42$. In $A \beta 14-23$, the incorporation of kd units at the middle and C-terminal (II and III, respectively) proximal to the $\mathrm{FF}$ region was found to impart effective aggregation-inhibition ability. Meanwhile, a single kd unit at the N-terminal (IV) away from the FF region turns out to be an aggregation enhancer due to its self-aggregation behaviour. The PF QNM-AFM study proved that the neuronal cells were grown with healthy cell-stiffness and other features in the presence of $\mathrm{V}$ under amyloid-induced stress conditions. The biocompatibility, enzymatic stability and non-self-aggregating properties combined with the effective modulation of $A \beta$ aggregation and ROS generation thus demonstrated $\mathrm{V}$ as a potential candidate to ameliorate amyloid-induced toxicity and adverse cellular mechanics.

\section{Experimental section}

\section{Aggregation kinetics study using ThT fluorescence}

The aggregation kinetics of peptide I (A $\beta 14-23)$ were studied in the presence and absence of peptidomimetics (II-V) using the thioflavin $\mathrm{T}(\mathrm{ThT})$ fluorescent dye $\left(\lambda_{\mathrm{ex}}=442 \mathrm{~nm}\right.$ and $\lambda_{\mathrm{em}}=$ $482 \mathrm{~nm})$. The peptide I $(25 \mu \mathrm{M})$ alone and with peptidomimetics $(25 \mu \mathrm{M})$ was incubated with ThT $(20 \mu \mathrm{M})$ for 20 days at $37^{\circ} \mathrm{C}$ in pH 2.0 (glycine- $\mathrm{HCl}$ buffer, $10 \mathrm{mM}$ ) and $\mathrm{pH} 7.4$ (PBS, $10 \mathrm{mM}$ ) under shaking conditions. ThT fluorescence was monitored in a time-dependent manner using a microplate reader (SpectrsMax i3x). The data were fitted to the following sigmoidal equation:

$$
y=y_{0}+\frac{y_{\max }-y_{0}}{1+e^{-\left(t-t_{1 / 2}\right) \kappa}}
$$

Where, $y$ denotes the fluorescence intensity at time $t, y_{0}$ and $y_{\max }$ indicate the initial and maximum fluorescence intensities, respectively, $t_{1 / 2}$ is the time required for half maximum of the fluorescence intensity (halfway from nuclei to fibrils), and $\kappa$ is the apparent first-order rate constant of aggregation. The lag time $\left(T_{\mathrm{Lag}}\right)$ was determined by $t_{1 / 2}-2 \kappa$.

\section{PF QNM-AFM imaging for $\mathrm{SH}-\mathrm{SY} 5 \mathrm{Y}$ cells}

The SH-SY5Y cells were cultured in glass bottom Petri dishes (14026-20, TEM PELLA, Inc.) using Dulbecco's modified Eagle medium/nutrient mixture (DMEM/F-12) media supplemented with $10 \%$ fetal bovine serum (FBS) and 1\% penicillin-streptomycin (PS) in a humidified $\mathrm{CO}_{2}(5 \%)$ incubator at $37{ }^{\circ} \mathrm{C}$. The cells were treated with pre-incubated $(48 \mathrm{~h}) \mathrm{A} \beta 42(20 \mu \mathrm{M})$ alone and with $\mathrm{Akd}^{\mathrm{NMC}}(20 \mu \mathrm{M})$ for $24 \mathrm{~h}$ under cell growing conditions. Then, the cells were washed with PBS (10 mM, pH 7.4) and fixed with $4 \%$ paraformaldehyde (PFA) solution. PeakForce Quantitative NanoMechanics-AFM (PF QNM-AFM) was used to acquire the AFM images of neuronal cells along with the nanoindentation parameter DMT modulus using a Bruker BIOSCOPE Resolve AFM Instrument with the PeakForce Tapping Technique. For fluid imaging, a non-conductive, backside reflective Au-coated silicon nitride (MCLT-BIO, force constant: $0.01 \mathrm{~N} \mathrm{~m}^{-1}$ ) tip of length $0.55 \mu \mathrm{m}$ and resonance frequency $7 \mathrm{kHz}$ was used. Finally, the images were processed using the NanoScope 1.8 analysis software (Bruker, Inc.).

\section{Neuronal rescue studies}

The ability of peptidomimetics (II-V) to rescue neuronal cells from amyloid-induced stress induced by A $\mathrm{\beta 14}-23$ (I) and $\mathrm{A} \beta 42$ was studied using the Alamar blue assay in the SH-SY5Y cell line. At first, the cells were cultured in a 96-well plate (15000 cells per well) using DMEM/F-12 medium (Gibco, Invitrogen) containing FBS $(10 \%)$ and PS $(1 \%)$. Then, the cell media was replaced with low serum (2\% FBS) containing DMEM/F-12 media. Next, the cells were treated $(24 \mathrm{~h})$ with the peptide I $(10 \mu \mathrm{M})$ and $\mathrm{A} \beta 42(10 \mu \mathrm{M})$, which were preincubated $(48 \mathrm{~h})$ at $\mathrm{pH} 7.4$ in the absence and presence of peptidomimetics $(10 \mu \mathrm{M})$. Finally, experimental cells were treated with Alamar blue solution for $2 \mathrm{~h}$ at $37^{\circ} \mathrm{C}$ and the absorbance was measured at $570 \mathrm{~nm}$ using a microplate reader. The data were plotted and analysed using the GraphPad prism software (one-way ANOVA).

\section{Membrane toxicity}

To determine the modulation of $\mathrm{A} \beta 42$-induced plasma membrane toxicity by peptidomimetics, we performed immunocytochemistry in the SH-SY5Y cell line. The cells were cultured in a $35 \mathrm{~mm}$ confocal dish using DMEM/F-12 medium (Gibco, Invitrogen) containing FBS (10\%) and PS (1\%) and treated $(3 \mathrm{~h})$ with $10 \mu \mathrm{M} \mathrm{A} \beta 42$ (fibrils) alone and preincubated with $\operatorname{Akd}^{\mathrm{NMC}}(10 \mu \mathrm{M})$. The cells were washed with PBS $(10 \mathrm{mM}, \mathrm{pH}$ 7.4) and fixed with 4\% PFA solution and the cells were again washed with PBS ( 3 times), and blocked using $5 \%$ bovine serum albumin (BSA). Next, the cells were treated with $\mathrm{A} \beta 42$ fibrilspecific primary antibody OC $(1: 250)$ for $16 \mathrm{~h}$ at $4{ }^{\circ} \mathrm{C}$ followed by treatment of red fluorescent-labelled $\left(\lambda_{\mathrm{ex}}=633 \mathrm{~nm}\right.$ and $\lambda_{\mathrm{em}}=$ $650 \mathrm{~nm})$ anti-mouse IgG secondary antibody $(1: 200)$. The excess antibody was washed using PBS and the cell nuclei were stained with DAPI for confocal imaging. The images were acquired using 
an OLYMPUS FLUOVIEW FV3000 confocal microscope and analysed using the cellSens software.

\section{Author contributions}

M. K. and D. G. contributed equally to performing the various experiments, data collection, analyses and preparation of the manuscript. D. G. performed the synthesis. D. G. and S. S. performed the cellular studies. M. K. performed the docking studies. T. G. designed and supervised the research and preparation of the manuscript.

\section{Conflicts of interest}

There are no conflicts to declare.

\section{Acknowledgements}

Authors thank JNCASR, SwarnaJayanti Fellowship (DST/SJF/ CSA-02/2015-2016), DST, India, and Shiva Prasad for the AFM study and Kavana for technical help.

\section{Notes and references}

1 Alzheimer's Disease Facts and Figures, Alzheimer's Dement., 2021, 17, 327-406.

2 D. J. Selkoe and J. Hardy, The Amyloid Hypothesis of Alzheimer's Disease at 25 years, EMBO Mol. Med., 2016, 8, 595-608.

3 T. P. J. Knowles, M. Vendruscolo and C. M. Dobson, The Amyloid State and Its Association with Protein Misfolding Diseases, Nat. Rev. Mol. Cell Biol., 2014, 15, 384-396.

4 K. Rajasekhar, M. Chakrabarti and T. Govindaraju, Function and Toxicity of Amyloid Beta and Recent Therapeutic Interventions Targeting Amyloid Beta in Alzheimer's Disease, Chem. Commun., 2015, 51, 13434-13450.

5 A. G. Kreutzer and J. S. Nowick, Elucidating the Structures of Amyloid Oligomers with Macrocyclic $\beta$-Hairpin Peptides: Insights into Alzheimer's Disease and Other Amyloid Diseases, Acc. Chem. Res., 2018, 51, 706-718.

6 P. H. Nguyen, et al., Amyloid Oligomers: A Joint Experimental/Computational Perspective on Alzheimer's Disease, Parkinson's Disease, Type Ii Diabetes, and Amyotrophic Lateral Sclerosis, Chem. Rev., 2021, 121, 2545-2647.

7 C. Cheignon, M. Tomas, D. Bonnefont-Rousselot, P. Faller, C. Hureau and F. Collin, Oxidative Stress and the Amyloid Beta Peptide in Alzheimer's Disease, Redox Biol., 2018, 14, 450-464.

8 D. A. Fletcher and R. D. Mullins, Cell Mechanics and the Cytoskeleton, Nature, 2010, 463, 485-492.

9 V. Lulevich, C. C. Zimmer, H.-s. Hong, L.-w. Jin and G.-y. Liu, Single-Cell Mechanics Provides a Sensitive and Quantitative Means for Probing A $\beta$ Peptide and Neuronal Cell Interactions, Proc. Natl. Acad. Sci. U. S. A., 2010, 107, 13872-13877.
10 Q. Gao, Y. Fang, S. Zhang, H. S. H. Wong, Y. E. Chan, S. S. M. Wong, K. K. L. Yung and K. W. C. Lai, Dynamic Effect of Beta-Amyloid 42 on Cell Mechanics, J. Biomech., 2019, 86, 79-88.

11 Y. Fang, C. Y. Y. Iu, C. N. P. Lui, Y. Zou, C. K. M. Fung, H. W. Li, N. Xi, K. K. L. Yung and K. W. C. Lai, Investigating Dynamic Structural and Mechanical Changes of Neuroblastoma Cells Associated with Glutamate-Mediated Neurodegeneration, Sci. Rep., 2014, 4, 7074.

12 Q. Luo, D. Kuang, B. Zhang and G. Song, Cell Stiffness Determined by Atomic Force Microscopy and Its Correlation with Cell Motility, Biochim. Biophys. Acta, Gen. Subj., 2016, 1860, 1953-1960.

13 T. M. Kruger, K. J. Bell, T. I. Lansakara, A. V. Tivanski, J. A. Doorn and L. L. Stevens, Reduced Extracellular Matrix Stiffness Prompts Sh-Sy5y Cell Softening and Actin Turnover to Selectively Increase $\mathrm{A} \beta(1-42)$ Endocytosis, ACS Chem. Neurosci., 2019, 10, 1284-1293.

14 X. Wang, R. Bleher, M. E. Brown, J. G. N. Garcia, S. M. Dudek, G. S. Shekhawat and V. P. Dravid, Nano-Biomechanical Study of Spatio-Temporal Cytoskeleton Rearrangements That Determine Subcellular Mechanical Properties and Endothelial Permeability, Sci. Rep., 2015, 5, 11097.

15 S. Corvaglia, B. Sanavio, R. P. Hong Enriquez, B. Sorce, A. Bosco, D. Scaini, S. Sabella, P. P. Pompa, G. Scoles and L. Casalis, Atomic Force Microscopy Based Nanoassay: A New Method to Study $\alpha$-Synuclein-Dopamine Bioaffinity Interactions, Sci. Rep., 2014, 4, 5366.

16 P. K. Viji Babu, C. Rianna, U. Mirastschijski and M. Radmacher, Nano-Mechanical Mapping of Interdependent Cell and Ecm Mechanics by AFM Force Spectroscopy, Sci. Rep., 2019, 9, 12317.

17 J. Hu, S. Chen, D. Huang, Y. Zhang, S. Lü and M. Long, Global Mapping of Live Cell Mechanical Features Using Peakforce QNM AFM, Biophys. Rep., 2020, 6, 9-18.

18 K. Rajasekhar, S. Samanta, V. Bagoband, N. A. Murugan and T. Govindaraju, Antioxidant Berberine-Derivative Inhibits Multifaceted Amyloid Toxicity, iScience, 2020, 23, 101005.

19 S. Samanta, K. Rajasekhar, M. Ramesh, N. A. Murugan, S. Alam, D. Shah, J. P. Clement and T. Govindaraju, Naphthalene Monoimide Derivative Ameliorates Amyloid Burden and Cognitive Decline in a Transgenic Mouse Model of Alzheimer's Disease, Adv. Ther., 2021, 4, 2000225.

20 J. Yao, X. Gao, W. Sun, T. Yao, S. Shi and L. Ji, Molecular Hairpin: A Possible Model for Inhibition of Tau Aggregation by Tannic Acid, Biochemistry, 2013, 52, 1893-1902.

21 A. J. Doig, M. P. del Castillo-Frias, O. Berthoumieu, B. Tarus, J. Nasica-Labouze, F. Sterpone, P. H. Nguyen, N. M. Hooper, P. Faller and P. Derreumaux, Why Is Research on Amyloid- $\beta$ Failing to Give New Drugs for Alzheimer's Disease?, ACS Chem. Neurosci., 2017, 8, 1435-1437.

22 C. Soto, E. M. Sigurdsson, L. Morelli, R. Asok Kumar, E. M. Castaño and B. Frangione, $\beta$-Sheet Breaker Peptides Inhibit Fibrillogenesis in a Rat Brain Model of Amyloidosis: Implications for Alzheimer's Therapy, Nat. Med., 1998, 4, 822-826. 
23 D. Maity, M. Howarth, M. C. Vogel, M. Magzoub and A. D. Hamilton, Peptidomimetic-Based Vesicles Inhibit Amyloid-B Fibrillation and Attenuate Cytotoxicity, J. Am. Chem. Soc., 2021, 143, 3086-3093.

24 S. Samanta, K. Rajasekhar, V. Babagond and T. Govindaraju, Small Molecule Inhibits Metal-Dependent and -Independent Multifaceted Toxicity of Alzheimer's Disease, ACS Chem. Neurosci., 2019, 10, 3611-3621.

25 B. Dai, et al., Tunable Assembly of Amyloid-Forming Peptides into Nanosheets as a Retrovirus Carrier, Proc. Natl. Acad. Sci. U. S. A., 2015, 112, 2996-3001.

26 A. Frydman-Marom, R. Shaltiel-Karyo, S. Moshe and E. Gazit, The Generic Amyloid Formation Inhibition Effect of a Designed Small Aromatic $\beta$-Breaking Peptide, Amyloid, 2011, 18, 119-127.

27 T. Ikenoue, F. A. Aprile, P. Sormanni and M. Vendruscolo, Rationally Designed Bicyclic Peptides Prevent the Conversion of A 342 Assemblies into Fibrillar Structures, Front. Neurosci., 2021, 15, 623097.

28 A. Abbott and E. Dolgin, Leading Alzheimer's Theory Survives Drug Failure, Nature, 2016, 540, 15-16.

29 N. Kokkoni, K. Stott, H. Amijee, J. M. Mason and A. J. Doig, N-Methylated Peptide Inhibitors of B-Amyloid Aggregation and Toxicity. Optimization of the Inhibitor Structure, Biochemistry, 2006, 45, 9906-9918.

30 A. Frydman-Marom, M. Convertino, R. Pellarin, A. Lampel, R. Shaltiel-Karyo, D. Segal, A. Caflisch, D. E. Shalev and E. Gazit, Structural Basis for Inhibiting B-Amyloid Oligomerization by a Non-Coded B-Breaker-Substituted Endomorphin Analogue, ACS Chem. Biol., 2011, 6, 1265-1276.

31 S. L. Bernstein, et al., Amyloid- $\beta$ Protein Oligomerization and the Importance of Tetramers and Dodecamers in the Aetiology of Alzheimer's Disease, Nat. Chem., 2009, 1, 326-331.

32 L. O. Tjernberg, J. Naslund, F. Lindqvist, J. Johansson, A. R. Karlstrom, J. Thyberg, L. Terenius and C. Nordstedt, Arrest of Beta Amyloid Fibril Formation by a Pentapeptide Ligand, J. Biol. Chem., 1996, 271, 8545-8548.

33 F. T. Senguen, N. R. Lee, X. Gu, D. M. Ryan, T. M. Doran, E. A. Anderson and B. L. Nilsson, Probing Aromatic, Hydrophobic, and Steric Effects on the Self-Assembly of an Amyloid- $\beta$ Fragment Peptide, Mol. BioSyst., 2011, 7, 486-496.

34 A. Henning-Knechtel, et al., Designed Cell-Penetrating Peptide Inhibitors of Amyloid-Beta Aggregation and Cytotoxicity, Cell Rep. Phys. Sci., 2020, 1, 100014.

35 M. Richman, S. Wilk, M. Chemerovski, S. K. T. S. Wärmländer, A. Wahlström, A. Gräslund and S. Rahimipour, In Vitro and
Mechanistic Studies of an Antiamyloidogenic Self-Assembled Cyclic D,L-A-Peptide Architecture, J. Am. Chem. Soc., 2013, 135, 3474-3484.

36 J. Luo and J. P. Abrahams, Cyclic Peptides as Inhibitors of Amyloid Fibrillation, Chemistry, 2014, 20, 2410-9.

37 J. Kaffy, et al., Designed Glycopeptidomimetics Disrupt Protein-Protein Interactions Mediating Amyloid $\beta$-Peptide Aggregation and Restore Neuroblastoma Cell Viability, J. Med. Chem., 2016, 59, 2025-2040.

38 C. Balachandra and T. Govindaraju, Cyclic DipeptideGuided Aggregation-Induced Emission of Naphthalimide and Its Application for the Detection of Phenolic Drugs, J. Org. Chem., 2020, 85, 1525-1536.

39 C. Balachandra, D. Padhi and T. Govindaraju, Cyclic dipeptide: A privileged molecular scaffold to derive structural diversity and functional utility, ChemMedChem, 2021, 16, 2558-2587.

40 A. D. Borthwick, 2,5-Diketopiperazines: Synthesis, Reactions, Medicinal Chemistry, and Bioactive Natural Products, Chem. Rev., 2012, 112, 3641-3716.

41 M. Li, S. E. Howson, K. Dong, N. Gao, J. Ren, P. Scott and X. Qu, Chiral Metallohelical Complexes Enantioselectively Target Amyloid B for Treating Alzheimer's Disease, J. Am. Chem. Soc., 2014, 136, 11655-11663.

42 M.-C. Hsieh, C. Liang, A. K. Mehta, D. G. Lynn and M. A. Grover, Multistep Conformation Selection in Amyloid Assembly, J. Am. Chem. Soc., 2017, 139, 17007-17010.

43 H. Abe, K. Kawasaki and H. Nakanishi, pH-Dependent Aggregate Forms and Conformation of Alzheimer Amyloid $\beta$-Peptide (12-24), J. Biochem., 2002, 132, 863-74.

44 A. Micsonai, F. Wien, L. Kernya, Y. H. Lee, Y. Goto, M. Refregiers and J. Kardos, Accurate secondary structure prediction and fold recognition for circular dichroism spectroscopy, Proc. Natl. Acad. Sci. U. S. A., 2015, 112, E3095-103.

45 G. Zandomeneghi, M. R. H. Krebs, M. G. McCammon and M. Fändrich, Ftir Reveals Structural Differences between Native Beta-Sheet Proteins and Amyloid Fibrils, Protein Sci., 2004, 13, 3314-3321.

46 R. Carrotta, M. Manno, D. Bulone, V. Martorana and P. L. San Biagio, Protofibril Formation of Amyloid $\beta$-Protein at Low Ph Via a Non-Cooperative Elongation Mechanism, J. Biol. Chem., 2005, 280, 30001-8.

47 S. Jin, N. Kedia, E. Illes-Toth, I. Haralampiev, S. Prisner, A. Herrmann, E. E. Wanker and J. Bieschke, A $\beta(1-42)$ Aggregation Initiates Its Cellular Uptake and Cytotoxicity, J. Biol. Chem., 2016, 291, 19590-19606. 